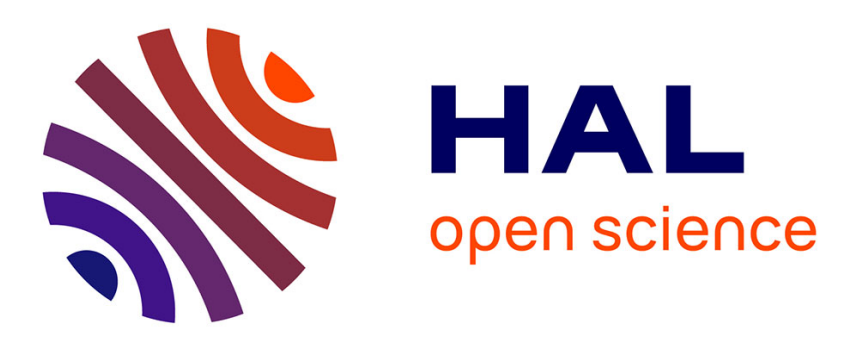

\title{
Electrochemical oxygen sensors for on-line monitoring in lead-bismuth alloys: status of development
}

\author{
J.-L. Courouau
}

\section{To cite this version:}

J.-L. Courouau. Electrochemical oxygen sensors for on-line monitoring in lead-bismuth alloys: status of development. Journal of Nuclear Materials, 2004, 335 (2), pp.254-259. 10.1016/j.jnucmat.2004.07.020 . cea-02869924v2

\section{HAL Id: cea-02869924 \\ https://hal-cea.archives-ouvertes.fr/cea-02869924v2}

Submitted on 17 Jun 2020

HAL is a multi-disciplinary open access archive for the deposit and dissemination of scientific research documents, whether they are published or not. The documents may come from teaching and research institutions in France or abroad, or from public or private research centers.
L'archive ouverte pluridisciplinaire HAL, est destinée au dépôt et à la diffusion de documents scientifiques de niveau recherche, publiés ou non, émanant des établissements d'enseignement et de recherche français ou étrangers, des laboratoires publics ou privés. 


\title{
Electrochemical oxygen sensors for on-line monitoring in lead bismuth alloys : status of development.
}

\author{
J-L. COUROUAU* \\ Commissariat à l'Energie Atomique (CEA), Centre d'étude de Cadarache, \\ 13108 Saint-Paul-Lez-Durance cedex, France
}

*Corresponding author:

J-L. COUROUAU

CEA Cadarache

DEN/DTN/STPA/LCP

F-13108 Saint-Paul-Lez-Durance cedex

Tel.: +33-4 42253266

Fax: +33-4 42257287

e-mail: jean-louis.courouau@cea.fr

Subject codes : 101 (impurities) ; C04 (chemical reactions) ; L03 (liquid metals) ; M08 (monitoring methods) ; Z01 (zirconium) 
Post-print version

Courouau, J. L. « Electrochemical oxygen sensors for on-line monitoring in lead-bismuth alloys: status of development ». Journal of Nuclear Materials 335, no 2 (2004): 254-59.

https://doi.org/10.1016/i.jnucmat.2004.07.020

\section{Abstract}

This paper presents the state of development of oxygen sensors based on the electromotive force (emf.) measurement at null current, using yttria stabilized zirconia as solid electrolyte for application in liquid lead-bismuth eutectic (LBE), which is envisaged as a nuclear coolant or as a spallation target in accelerator driven system (ADS) for nuclear wastes transmutation. The assembly procedure, the calibration method, as well as the summary of the various validation tests undergone both in static and in loop facilities are presented so as to define a real state of achievement and the basics needs for further studies. The sensors are efficient, accurate, rapid and reliable for research loops. However, the poor mechanical resistance as well as the effect of traces of impurities, promoting an increasing time-drift under certain conditions, are to be further studied to improve the sensor reliability for a nuclear use. The oxygen and chromium solubilities were reassessed in the process of the sensor testing, those relations are also given and discussed.

\section{Introduction}

The accurate measurement of the oxygen concentration in liquid lead-bismuth eutectic, as well as in pure lead alloys for use as a coolant in nuclear systems or as a liquid spallation target for the high neutron source of an ADS, which is foreseen for nuclear waste transmutation [1] [2], is a critical issue to define the active chemistry control and monitoring systems. The contamination of the liquid system by lead and bismuth oxides must be controlled for reliable and safe operation, as this can affect the ability of the fluid to flow and to extract the heat by clogging in the pipes or by depositing on the heat exchanger surface. The second requirement is to ensure an efficient corrosion protection of the structure if the oxide layer self-healing method is chosen, as well as to control the distribution of the activated products (fission, spallation, corrosion) within the liquid system, where oxygen is playing a key role.

The use of the ionic conduction properties of some solid electrolytes, and in particular the zirconia based ceramic, allows making an electrochemical cell assembly for on-line measurement of dissolved oxygen in a liquid metal system in a wide concentration range. This has been already addressed in previous papers [3] [4]. The main objective was first to investigate the possibility to build an oxygen sensor for liquid lead alloy applications, and in particular to check whether the sensor outputs were reliable enough to operate the oxygen control processes. This is verified through the development of a specific calibration procedure. In addition, the second point was to assess its main operating characteristics so as to define its serviceability for pilot scale applications to real size nuclear system such as the spallation target loop or the coolant loop of a nuclear system (fast or sub-critical ADS system). It should be noticed that the Russian Federation paved the way to this development years ago [5] [6] by developing this technology for nuclear naval propulsion, as well as the Harwell company [7] for similar liquid sodium sensors that have been used in CEA for more than 25 years on experimental loops.

\section{Theoretical relation}

The theoretical formulation of the sensor output, based on the Nernst relation, was previously addressed in [4], but with slightly inaccurate free energies of formation for the various oxides (reference electrode oxide, lead alloy oxides), as they were computed by the mean least squares method on the full temperature range ( $300 \mathrm{~K}$ to $1300 \mathrm{~K}$ or more). Using the HSC 
chemistry database software [8], the range was downsized to a more relevant operating temperature that could be expected for a real application, $400 \mathrm{~K}$ to $1000 \mathrm{~K}$, and the results are presented in Table 1. The free energies are then in good agreement with the respective energies used elsewhere using other databases ([9]: JANAF; [10]: I. BARIN 1989; [11]: the Oxide Handbook, 1982). The slight inaccuracy of these data will affect the theoretical electromotive force (emf.) calculation by a few millivolts $(\mathrm{mV})$ that are assumed as reasonable. Another source of scattering is due to the data coming from the lead activity relation in LBE, which affect only slightly the emf by a maximum of $10 \mathrm{mV}$, as well as from the oxygen solubility relation, which can affects the emf to a much greater extent. However, there is only one available relation for LBE, known as the Orlov relation [5], whose accuracy and measurement method are not very well known. The constants of the Nernst relations are recalculated using the latest free energies and using the same data as those described in [4] and reported in respectively Table 2 and Table 3 (theory lines) for $\mathrm{Bi} / \mathrm{Bi}_{2} \mathrm{O}_{3}$ and $\mathrm{In} / \mathrm{In}_{2} \mathrm{O}_{3}$ reference electrodes for a cell immersed into a LBE solution according to the following emf. (E) versus temperature $(\mathrm{T})$ and oxygen concentration $\left(\mathrm{C}_{\mathrm{o}}\right)$ relationships:

$$
\begin{array}{ll}
E_{(m V)}=K_{1}+K_{2} \cdot T_{(K)}+K_{3} \cdot T_{(K)} \cdot \ln C_{o(p p m \text { weight })} & \text { for E }>\mathrm{E}^{\text {sat }} \\
E_{(m V)}^{S A T}=K+K^{\prime} \cdot T_{(K)} & \text { for E = Esat }
\end{array}
$$

Apart from the data used for the theoretical assessment, there may be other causes for the sensor not to behave according to the theoretical relations [12] [13]: the electrolyte conduction properties (slight electronic conduction, impurities in the ceramic, etc.), the influence of the reaction at the electrode/electrolyte interface (liquid metal/zirconia reaction, or even traces of impurities depositing on the interface), the cell irreversibility (equilibrium not reached due to an oxygen transfer rate limitation especially at very low oxygen partial pressure), as well as the instrumental uncertainties. This is why a calibration method was developed.

\section{Calibration, results and discussion}

The procedure for the assembly of home-made sensor is now routine, as well as the procedure for the calibration based on the temperature variation when the oxygen is close to saturation. They have been described in [4]. This calibration procedure has been systematically applied to all sensors built, at least one time for each sensor, in a simple crucible operating in a common purified argon atmosphere gloves box ("JACOMEX"). Up to now, up to 32 sensors were assembled following the principle given in [4]. The assembly procedure was applied 5 times since then (lot numbered $3 \mathrm{x}$ to $7 \mathrm{x}$, the first digit stands for the lot number while the $\mathrm{x}$ stands for the rank of the sensor in the assembly procedure): 20 Bismuth reference sensors (mp. $\left.271^{\circ} \mathrm{C}\right), 12$ Indium reference sensors $\left(\mathrm{mp} .157^{\circ} \mathrm{C}\right)$ were built.

Although the procedure of calibration is considered to be slightly inaccurate, the voltage linear regression coefficients for both domains, either the dissolved oxygen or the saturated oxygen solution, are almost always higher than 0.9 , indicating a variation according to the Nernst relations. However, other operating conditions affect the calibration result: the same procedure applied several times yields slightly different coefficients for the E vs. (T, Co) relation. For this, the only interpretation is to consider a slight irreversibility of the cell. The electrodes are not fully at thermodynamic equilibrium as the solution is static. Hence, the impurities may be dissolved or crystallized and there are probably some reactions on the electrolyte interface with the other dissolved impurities like the corrosion products $(\mathrm{Fe}, \mathrm{Ni}$, 
Cr) affecting eventually the electrode potential. To support this assumption, the results obtained for an inert crucible (aluminized steel by the pack cementation process) compared to those obtained with a steel crucible appear as more reliable as the linear regression coefficients are higher. This is especially true when the temperature gets below the $350^{\circ} \mathrm{C}$ threshold for a steel crucible: the level of impurities is then within the same range of concentration of the dissolved oxygen $(0.1$ weight $\mathrm{ppm})$ and the saturated line is no more linear.

This is why the coefficients of the $\mathrm{E}$ vs $(\mathrm{Co}, \mathrm{T})$ relations are averaged to smooth these influences on the calibration results for a lot of sensors identically built. The results of the calibration achieved are presented in Table 2 and Table 3 respectively for the $\mathrm{Bi}$ and the Indium reference sensors.

In addition, the quality of the solid electrolyte itself plays a role in the results. When the yttria-doped zirconia comes from a different fabrication batch, small variations probably caused by impurities in the yttria and zirconia powders used or small variations in the fabrication procedure are affecting the calibration results. This should be further studied.

Despite this slight scattering, the agreement between the experimental sensor outputs and the theoretical predictions must be recognized as rather good. The accuracy is assessed within 5\% of the voltage readings ( $25 \mathrm{mV}$ maximum scattering for a $500 \mathrm{mV}$ reading) that affect the concentration by $40 \%$ for the high concentration range to $80 \%$ for the low concentration range. The general relations, using the constant mean values given in Table 2 and Table 3 , are then recommended instead of the theoretical constants when calibration is not possible. Figure 1 presents the calibration curves plotted against the theoretical curves.

Calibration is, in any case, recommended to achieve a better accuracy. However, the availability of a method to achieve a calibration on the field would be most useful to significantly increase the accuracy on the long term, as well as to regularly assess the good operation of a sensor. This could be particularly critical if the time drift that was observed on some occasion is confirmed. Indeed, other impurities may react at the solid electrolyte interface and form metal/metal oxide couples, which interfere with the electrode potential on the long term. In any case, this procedure and results have to be compared to other procedure and calibration results to better assess the accuracy of the calibration procedure as well as to understand the potential side effects.

\section{Oxygen and chromium solubility}

It was previously stated that the only available oxygen solubility data were poorly known compared to the other required thermodynamic data. However, it is possible to use the calibration results to retrofit the oxygen solubility coefficients, $\mathrm{A}$ and $\mathrm{B}$, as given in Equation 3 , in the relevant temperature range where the calibrations were done: $350^{\circ} \mathrm{C}<\mathrm{T}<500^{\circ} \mathrm{C}$.

$$
\ln C_{o(w g t \%)}^{*}=A-\frac{B}{T_{(K)}} \quad \text { with } A=\frac{K^{\prime}-K_{2}}{K_{3}} \text { and } B=\frac{K_{1}-K}{K_{3}}
$$

By using the following relation and the mean constants derived for each reference systems, indium and bismuth mean values given in Table 2 and Table 3, it is possible to assess new solubility coefficients by meaning the two references: $A=7.7 ; B=11426$. This calculation is assuming that the mean value of both sensors, indium and bismuth, will reduce all experimental uncertainties as well as the intrinsic property variations of the solid electrolyte. When compared to the Orlov relation $(A=2.76$; $B=7828.8)$, the solubility would be lower by 
Post-print version

Courouau, J. L. « Electrochemical oxygen sensors for on-line monitoring in lead-bismuth alloys: status of development ». Journal of Nuclear Materials 335, no 2 (2004): 254-59.

https://doi.org/10.1016/i.jnucmat.2004.07.020

half at $350^{\circ} \mathrm{C}$ and about 2 times higher at $500^{\circ} \mathrm{C}$. There is however a rather good agreement with the coefficients achieved by $\mathrm{V}$. Ghetta [15] by coulometric titration measurements in LBE $(A=7.55 ; B=11173)$, whereas the coefficients calculated by $G$. Mueller [14] $(A=2.52$; $\mathrm{B}=4803$ ) are slightly lower at any temperature as presented in Figure 2 . The solubility should then be further studied as this could have an impact on the specification for a nuclear operating system as regards the coolant chemistry control.

Considering that the oxygen is at equilibrium with the saturated chromium impurity following the $\mathrm{Cr} / \mathrm{Cr}_{2} \mathrm{O}_{3}$ equilibrium (Equation 4) in specific and very reductive conditions, it is possible to derive the saturated dissolved chromium concentration in the LBE solution by knowing the temperature variation of the oxygen concentration. This requires the following assumptions: the chromium activity is defined by the molar ratio, the $\mathrm{PbO}$ and $\mathrm{Pb}$ activities are defined as presented in [4], and the Orlov relation is used for the oxygen solubility. The free energy of the reaction is assessed using the data from HSC [8] in the $400 \mathrm{~K}-1000 \mathrm{~K}$ temperature range, and is given in Equation 5.

$$
\begin{aligned}
& \frac{4}{3} \mathrm{Cr}_{(\text {dissolved })}+2 P b O_{(\text {dissolved })} \Leftrightarrow \frac{2}{3} \mathrm{Cr}_{2} \mathrm{O}_{3(\text { solid })}+2 P b_{(\text {liquide })} \\
& \Delta_{r} G_{(\mathrm{J} / \mathrm{mol})}^{o}=-317800-27.3 \cdot T(K)
\end{aligned}
$$

Such a variation is presented in Figure 3: it was obtained in the BIP static facility after hydrogen reduction. Hundredth of hours of operation of the static device, which was including some metallic parts wetted in LBE (SS304 steel), were achieved at that moment, so that the effective saturation of chromium could be assumed. Using the experimental relation presented in Figure 3, the chromium solubility is then calculated:

$$
\ln C_{C r(\text { weigth ppm })}=11.68-\frac{6959.25}{T_{(K)}} \quad \text { for } 370^{\circ} \mathrm{C}<\mathrm{T}<540^{\circ} \mathrm{C}
$$

The relation is surprisingly very close to the Russian only available relation [6], whose coefficients are respectively 9.164 and 5250. For instance, the concentrations calculated are respectively 3.9 weight ppm at $400^{\circ} \mathrm{C}$ for the Russian relation and 3.8 weight ppm for this study. On that particular occasion, the lowest oxygen concentration that was ever observed in our facilities was measured: $10^{-11}$ weight $\mathrm{ppm}$ at $370^{\circ} \mathrm{C}$.

\section{Results and discussion}

Sensors have been tested for thousand of hours in LBE solution in both static (BIP [4], COLIMESTA [3] [4], JACOMEX [4] and wetting tests gloves boxes, COXCIMEL [15]) and dynamic conditions (CICLAD, LiSoR, and STELLA loops) in stable or cycling chemical conditions that validate their effective and reliable use although some limiting behaviors appeared. These tests allowed gaining a large operating feedback representative of long-term operations on a wide variety of operating conditions. The characteristics observed up to now on these oxygen prototypes sensors are then satisfactorily and confirm the previous observations [4], as regards the operating range $\left(370^{\circ} \mathrm{C}-550^{\circ} \mathrm{C}\right)$, the oxygen concentration range, the response time, the accuracy and reproducibility, as well as the service life (up to 4000 hours observed, but longer expected in stable conditions). A Lower operating temperature than $350^{\circ} \mathrm{C}$ is possible but with a lower accuracy as the sensor outputs deviate 
Post-print version

Courouau, J. L. « Electrochemical oxygen sensors for on-line monitoring in lead-bismuth alloys: status of development ». Journal of Nuclear Materials 335, no 2 (2004): 254-59.

https://doi.org/10.1016/i.jnucmat.2004.07.020

from ideal behavior most probably because of an increasing irreversibility of the cell (Figure $3)$.

Limiting factors were clearly pointed out from the sensors operations that question their reliability for long-term operation on a nuclear facility : little mechanical resistance, and the effect of the impurities on the long term for high oxygen content.

On static devices, almost no sensor breakdown was observed so long that no thermal or mechanical shocks were ensured. For instance, 3 zirconia thimbles were broken on the same day when skimming out superficial oxide during the calibration operation. Another sensor breakdown is illustrated on Figure 4. In a dynamic facility, the vibrations due to turbulent flow especially enhanced by the length of the zirconia tube, led to the failure of a number of sensors, both for protected (LiSoR) or unprotected (CICLAD, 4 in one year) sensors. The use of a metallic sheath clearly protected the ceramic for a longer time. The local flow conditions appeared to be important, as reduced turbulence as well as lower flow velocity should be favored.

However, the use of a proper design for the ceramic housing, together with the use of special care for operation would allow reducing these causes of failure. This was typically used for the liquid sodium sensor (Westinghouse, Harwell [7]) and is known as efficient. Although the closed-end tube shape is commercially available and easily separates the 2 electrodes, the working and the reference electrodes, it might be replaced by other less fragile shapes, like a conical shape or a pellet shape fused to alumina tube for instance that is reported as more resistant [13]. However, the implementation becomes more complex because of the issue of the metal-to-ceramic or ceramic-to-ceramic sealing, without speaking of the cost.

The time drift appeared as negligible with low oxygen concentration and stable operating conditions. On the other hand, high oxygen content or cycling the oxygen from low to high contents, affects the sensor output on the long term by clearly increasing the time drift, and eventually preventing any oxygen measurement. The other impurities present in the liquid metal, and especially those generated by a steel sheath close to the electrolyte, may deposit on the electrolyte interface, affecting eventually the electrode potential. The potential recovery operations, like high temperature in low oxygen washing operation, or nitric acid washing of the ceramic, should be studied as well as the basic phenomena involved.

\section{Conclusion}

Assembly and calibration procedures were achieved. A large testing in various conditions allowed defining a real state of achievement for the oxygen sensor. The basic static and loop implementation of the oxygen sensing ceramic proved efficient and gave reliable information for research studies. However, their uses are still not straight forward, especially for dynamic loop facilities, as a time drift apparently due to the long term influence of the impurities, as well as a fragile ceramic are observed. This makes the device not fully reliable for nuclear implementation yet, but should be solved by a proper design for the ceramic housing together with the use of special care for operation. The time drift due to the impurity effects, if confirmed, should be solved by a recovery procedure, whose possibility is to be studied as well. The time drift must be monitored on the long term, so that on-the-field calibration procedure is required.

In addition, the oxygen sensor could measure more than just oxygen. Indeed, assuming that equilibrium prevails amongst dissolved oxygen and the other solutes, it is possible to determine the concentration of other solutes from the oxygen sensor measurement, as was 
Post-print version

Courouau, J. L. « Electrochemical oxygen sensors for on-line monitoring in lead-bismuth alloys: status of development ». Journal of Nuclear Materials 335, no 2 (2004): 254-59.

https://doi.org/10.1016/i.jnucmat.2004.07.020

presented for the chromium solubility, similarly to the steel making industry that measure the dissolved carbon by this method.

\section{Acknowledgement}

This work has been performed within the CEA framework of the transmutation studies for nuclear waste radio toxicity reduction, and was supported as well by the $5^{\text {th }}$ European program (TECLA, Technologies for transmutation). The close collaboration and support of V. Ghetta from CNRS-LTPCM, F. Balbaud, P. Deloffre and C. Delisle from CEA/SCCME, as well as from H. Glassbrenner from PSI/FZK, is here acknowledged.

\section{References}

[1] Technologies for lead alloys, contracts $\mathrm{n}^{\circ}$ FIKW-CT-2000-00092, European commission, 5th EURATOM FRAMEWORK PROGRAMME 1998-2002.

[2] D. Warin, Transmutation studies in Europe, Revue générale du nucléaire (RGN) $n^{\circ} 4$, Août-Septembre 2002.

[3] J-L. Courouau, P. Trabuc, G. Laplanche, P. Deloffre, P. Taraud, M. Ollivier, R. Adriano, S. Trambaud, Journal of Nuclear Materials 301 (2002) 53-59.

[4] J-L. Courouau, P. Deloffre, R. Adriano, Journal de Physique IV France 12 (2002), Pr8 $141-153$.

[5] B.A. Shmatko, A.E. Russanov, Materials Science, vol.36, N5, 2000.

[6] F. Gromov, Yu. I. Orlov, P. N. Martynov, V. A. Gulevski, Proceedings of the conference HLMC 98, Obninsk: SSC RF-IPPE, Oct. 5-9,1998.

[7] R. C. Asher, D. C. Harper, T. B. A. Kirstein, F. Leach, R. G. Taylor, 4th International Conference on Liquid Metal Engineering and Technology, 17-21 October 1988, Avignon

[8] Chemical reaction and equilibrium software, Outokumpu HSC Chemistry for windows version 4.1.

[9] J. Konys, H. Muscher, Z. Voss, O. Wedemeyer, Journal of Nuclear Materials, 296 (2001) 289 - 294

[10] J. A. Fernandez, J. Abella, J. Barcelo, L. Victori, Journal of Nuclear Materials 301 (2002) 47-52

[11] N. Li, Journal of Nuclear Materials 300 (2002) 73-81.

[12] V. Ghetta, J. Fouletier, M. Henault, A. Le Moulec, Journal de Physique IV France 12 (2002), Pr8 123 - 140.

[13] E. C. Subbarao, Solid electrolyte and their applications, Plenum press, 1980.

[14] G. Müller, A. Heinzel, G. Schumacher, A. Weisenburger, Journal of Nuclear Materials, 321 (2003) 256 - 262

[15] V. Ghetta, To be published. 
Post-print version

Courouau, J. L. « Electrochemical oxygen sensors for on-line monitoring in lead-bismuth alloys: status of development ». Journal of Nuclear Materials 335, no 2 (2004): 254-59.

https://doi.org/10.1016/i.jnucmat.2004.07.020

\section{Figure and Table captions :}

Figure 1: Predicted $\mathrm{Bi} / \mathrm{Bi}_{2} \mathrm{O}_{3}$ sensor outputs by using either the calibrated or the theoretical relations for the saturation line and the iso-concentration line of 1 weight $\mathrm{ppm}$.

Figure 2: Comparison of the oxygen solubility relations.

Figure 3: Oxygen measurement after hydrogen $\left(\mathrm{Ar}+4 \% \mathrm{H}_{2}\right.$ specially prepared) reduction at $540^{\circ} \mathrm{C}$ in the BIP static facility where the chromium saturation is assumed and using the calibrated constants for the emf. conversion from the oxygen sensor output $\left(\mathrm{r}^{2}\right.$ being the linear regression coefficient).

Figure 4: Details of the $\mathrm{Bi} / \mathrm{Bi}_{2} \mathrm{O}_{3}$ reference electrode featured on a broken sensor.

Table 1: Main oxides free enthalpy coefficients for the $400 \mathrm{~K}-1000 \mathrm{~K}$ temperature range for one mole of $\mathrm{O}_{2}$.

Table 2: Synthesis of the $\mathrm{Bi} / \mathrm{Bi}_{2} \mathrm{O}_{3}$ sensors calibration results $\left(\mathrm{K}_{3}=-0,0431 \mathrm{mV} / \mathrm{K}\right)$.

Table 3: Synthesis of the $\mathrm{In} / \mathrm{In}_{2} \mathrm{O}_{3}$ sensors calibration results $\left(\mathrm{K}_{3}=-0,0431 \mathrm{mV} / \mathrm{K}\right)$. 


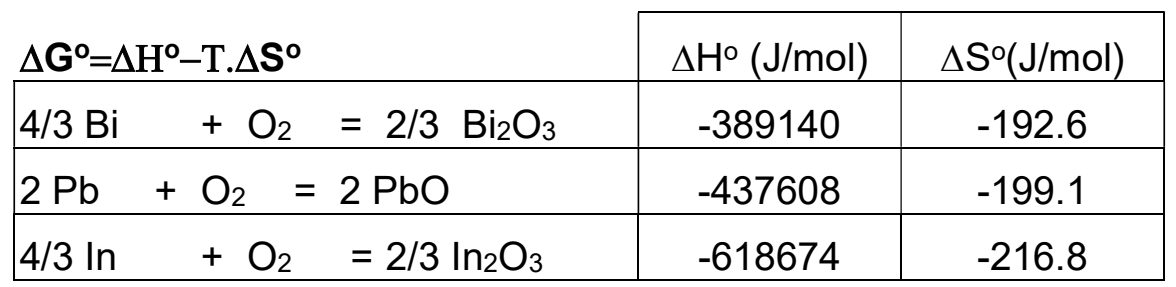

Table 1: Main oxides free enthalpy coefficients for the $400 \mathrm{~K}-1000 \mathrm{~K}$ temperature range expressed in $\mathrm{J} / \mathrm{mol}$ of $\mathrm{O}_{2}$.

\begin{tabular}{|c|c|c|c|c|}
\cline { 2 - 5 } \multicolumn{1}{c|}{} & $\mathrm{K}(\mathrm{mV})$ & $\mathrm{K}^{\prime}(\mathrm{mV} / \mathrm{K})$ & $\mathrm{K}_{1}(\mathrm{mV})$ & $\mathrm{K}_{2}(\mathrm{mV} / \mathrm{K})$ \\
\hline Theory & 120 & -0.054 & -218 & 0.065 \\
\hline $3 \mathrm{x}$ & $127 \pm 4$ & $-0,054 \pm 0,007$ & $-343 \pm 21$ & $0,27 \pm 0,03$ \\
\hline $4 \mathrm{x}$ & $118 \pm 2$ & $-0.036 \pm 0.003$ & $-402 \pm 35$ & $0.33 \pm 0.05$ \\
\hline $5 x$ & $140 \pm 7$ & $-0.07 \pm 0.001$ & $-283 \pm 19$ & $0.17 \pm 0.03$ \\
\hline $6 x$ & $133.5 \pm 0.2$ & $-0.0584 \pm$ & $-298 \pm 10$ & $0.19 \pm 0.01$ \\
\hline $7 x$ & $165 \pm 4$ & $-0.117 \pm 0.007$ & $-289 \pm 15$ & $0.180 \pm 0.02$ \\
\hline Mean & 137 & $-\mathbf{0 . 0 6 7}$ & $-\mathbf{3 2 3}$ & $\mathbf{0 . 2 3}$ \\
\hline
\end{tabular}

Table 2: Synthesis of the $\mathrm{Bi} / \mathrm{Bi}_{2} \mathrm{O}_{3}$ sensors calibration results $\left(\mathrm{K}_{3}=-0,0431 \mathrm{mV} / \mathrm{K}\right)$.

\begin{tabular}{|c|c|c|c|c|}
\cline { 2 - 5 } \multicolumn{1}{c|}{} & $\mathrm{K}(\mathrm{mV})$ & $\mathrm{K}^{\prime}(\mathrm{mV} / \mathrm{K})$ & $\mathrm{K}_{1}(\mathrm{mV})$ & $\mathrm{K}_{2}(\mathrm{mV} / \mathrm{K})$ \\
\hline $4 \mathrm{x}$ & $-439 \pm 6$ & $-0.04 \pm 0.007$ & $-958 \pm 38$ & $0.33 \pm 0.05$ \\
\hline $5 \mathrm{x}$ & $-394 \pm 9$ & $-0.1 \pm 0.01$ & $-920 \pm 20$ & $0.3 \pm 0.03$ \\
\hline $6 \mathrm{x}$ & $-464 \pm 18$ & $-0.016 \pm 0.03$ & $-997 \pm 32$ & $0.41 \pm 0.04$ \\
\hline $7 \mathrm{x}$ & -351.5 & -0.1672 & -873.5 & 0.235 \\
\hline Mean & $-\mathbf{4 1 2}$ & $-\mathbf{0 . 0 5 1}$ & $-\mathbf{9 3 7}$ & $\mathbf{0 . 3 2}$ \\
\hline
\end{tabular}

Table 3: Synthesis of the $\mathrm{In} / \mathrm{In}_{2} \mathrm{O}_{3}$ sensors calibration results $\left(\mathrm{K}_{3}=-0,0431 \mathrm{mV} / \mathrm{K}\right)$. 


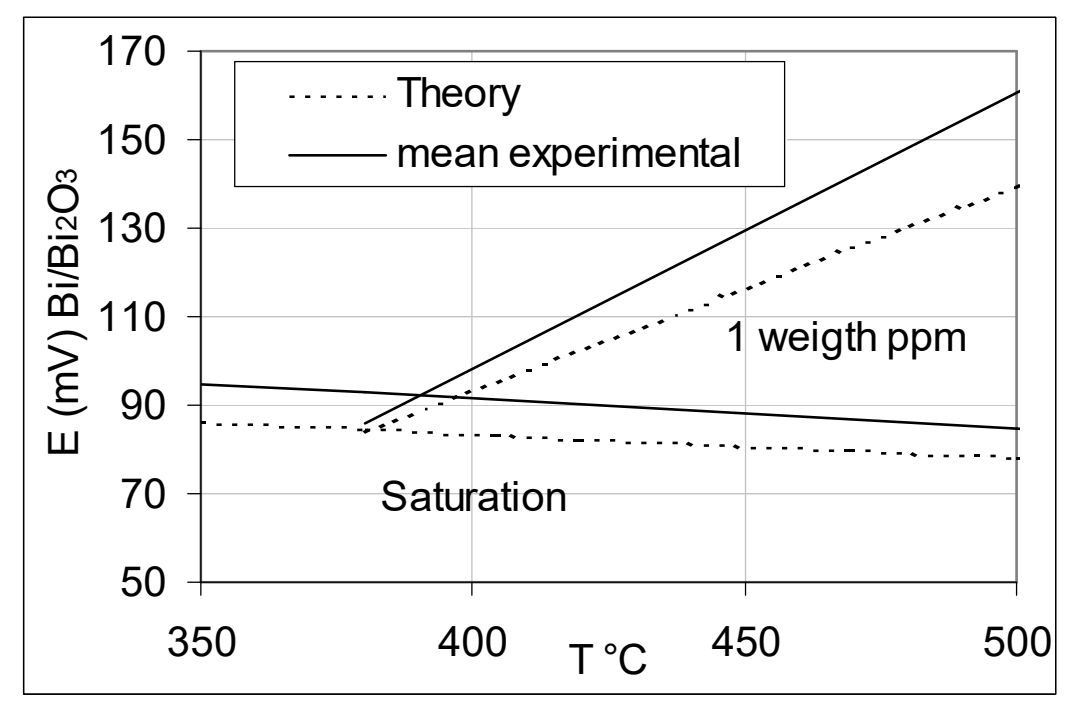

Figure 1: Predicted $\mathrm{Bi} / \mathrm{Bi}_{2} \mathrm{O}_{3}$ sensor outputs by using either the calibrated or the theoretical relations for the saturation line and the iso-concentration line of 1 weight $\mathrm{ppm}$.

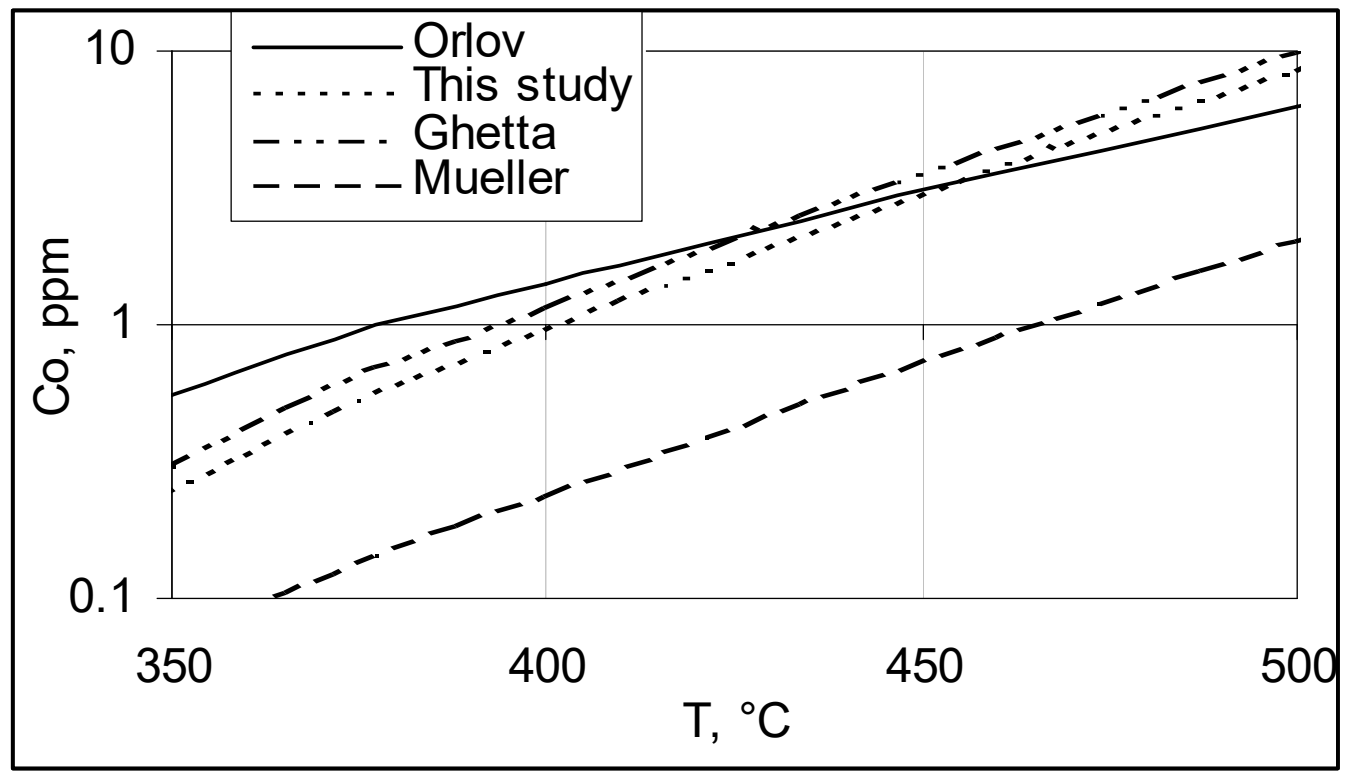

Figure 2: Comparison of the oxygen solubility relations. 


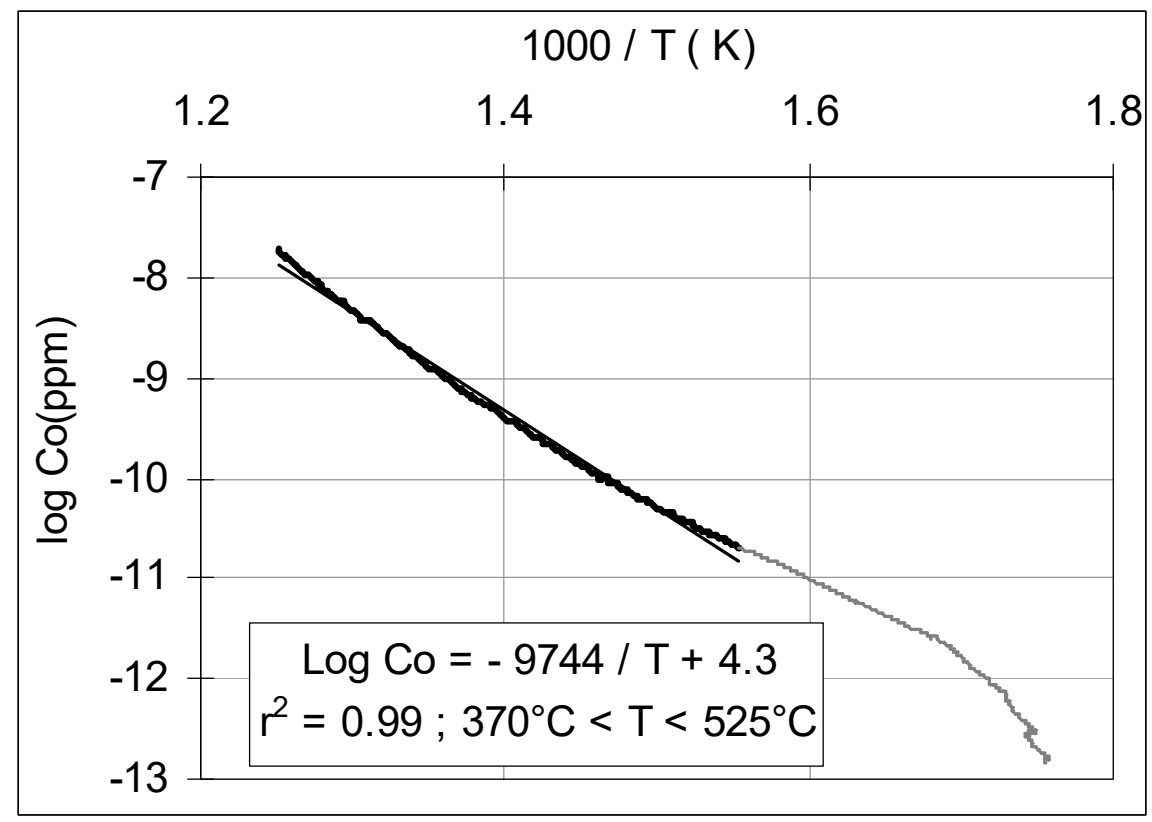

Figure 3: Oxygen measurement after hydrogen $\left(\mathrm{Ar}+4 \% \mathrm{H}_{2}\right.$ specially prepared) reduction at

$540^{\circ} \mathrm{C}$ in the BIP static facility where the chromium saturation is assumed and using the calibrated constants for the emf. conversion from the oxygen sensor output ( $\mathrm{r}^{2}$ being the linear regression coefficient).

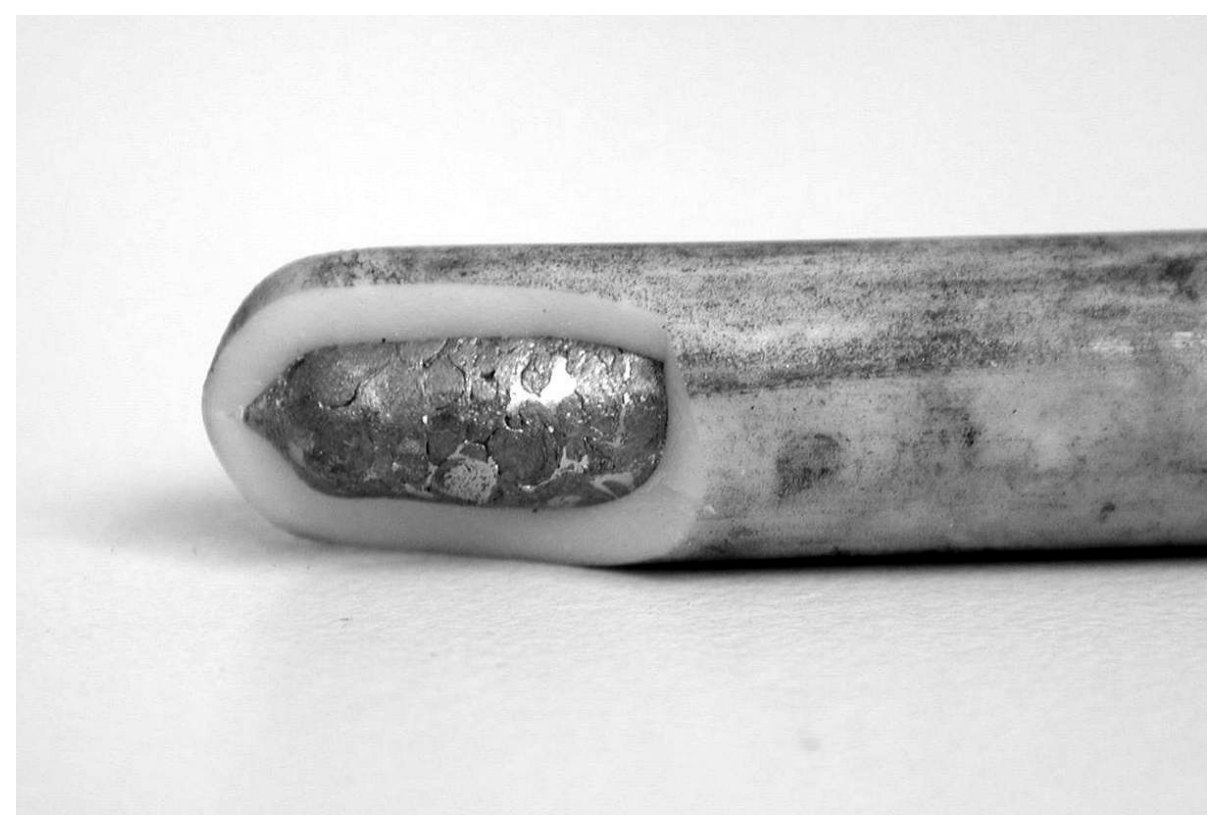

Figure 4: Details of the $\mathrm{Bi} / \mathrm{Bi}_{2} \mathrm{O}_{3}$ reference electrode featured on a broken sensor. 